\title{
Žemaitukų veislès žirgų kraujo rodiklių kitimas ištvermės sporto varžybų metu
}

\section{Zoja Miknienè,}

Audrius Kučinskas

Lietuvos sveikatos mokslu universitetas, Veterinarijos akademija,

Tilžés g. 18, LT-47181 Kaunas

El.paštas:mikniene@lva.lt
Darbo tikslas - ištirti ir įvertinti žemaitukų veislès žirgų kraujo biocheminių ir morfologinių rodiklių kitimą ištvermès sporto varžybų metu. Tyrimams naudoti 40-ties kliniškai sveikų, ịvairaus amžiaus žemaitukų veislès žirgų kraujo mėginiai. Žirgai dalyvavo ištvermès sporto varžybose (Kurtuvenuose ir Tytuvenuose), bėgo $32 \mathrm{~km}$ ištvermès trasą. Atlikus kraujo mėginių morfologinius ir biocheminius tyrimus prieš ir po varžybų, nustatyta, kad bendras leukocitų (WBC) $(\mathrm{p}<0,05)$ ir bendras eritrocitu $(\mathrm{RBC})(\mathrm{p}<0,05)$ kiekiai, hemoglobino $(\mathrm{Hb})(\mathrm{p}<0,001)$ koncentracija ir hematokrito (HCT) $(\mathrm{p}<0,001)$, hemoglobino vidutinis tūris $(\mathrm{MCH})$ $(\mathrm{p}<0,05)$, vidutinè hemoglobino koncentracija $(\mathrm{MCHC})(\mathrm{p}<0,05)$ ir bendras trombocitų (PLT) $(\mathrm{p}<0,05)$ kiekiai statistiškai patikimai didesni nei prieš varžybas. Nustatyta, kad po varžybų žemaitukų veislès žirgų kraujo serume vidutinis bendrujų baltymų kiekis $(\mathrm{TP})$ statistiškai patikimai $(p<0,01)$ mažesnis nei prieš varžybas, atitinkamai mažesnis ir albumino (Alb) kiekis $(p<0,05)$. Gliukozès (Glu), kreatinino (Crea), natrio (Na) kiekiai, gliutamiltransferazès fermento (GGT) aktyvumas ( $p<0,001)$, kaip ir bendro kreatinkinazès fermento $(\mathrm{CK}-\mathrm{NAC})(\mathrm{p}<0,01)$, statistiškai patikimai didesni nei prieš varžybas. Nustatyta, kad fermentų aspartataminotrasferazès (AST), alaninaminotrasferazès (ALT) ir širdies raumens kreatinkinazès (CK-MB) aktyvumai, kalio $(\mathrm{K})$, kalcio $(\mathrm{Ca})$ ir fosforo $(\mathrm{P})$ kiekiai statistiškai nepatikimai didesni nei prieš varžybas, o šlapalo (Urea), magnio $(\mathrm{Mg})$ kiekiai ir fermento šarminès fosfotazès (ALP) aktyvumas - mažesni. Nustatyta, kad varžybų metu organizme vyksta reikšmingi morfologiniai ir biocheminiai kraujo rodiklių kitimai.

Raktažodžiai: žemaitukai, ištvermè, kraujo morfologija, kraujo biochemija

\section{IVADAS}

Šiandien žirgai yra išbandomi, jie startuoja ištvermès lenktynèse. Labiausiai konkurencingos, „karštakraujams" priskiriamos, Arabų, Mustangų, grynakraujų jojamujų ir kitos veislès (Prince et al., 2001; Bergero et al., 2005; Fielding et al., 2011).

Žirgų sportas - ganètinai jauna ir sparčiai populiarejjanti sporto šaka ne tik pasaulyje, bet ir Lietuvoje. Veterinarijos gydytojams iškyla daugybe klausimų, kaip teisingai kontroliuoti žirgo pasirengimą rungtynèms. Prieš 15-20 metų pasikeitè reikalavimai norintiems dalyvauti ištvermès sporto varžybose. Ribojamas greitis, ilginamas bėgimo atstumas, didesnis dèmesys skiriamas žirgo adaptacinèms or- ganizmo funkcijoms atgauti (kvejpavimo dažnio, širdies dažnio atsistatymas po krūvio), šlubavimui.

Sunkaus fizinio krūvio metu raumenų ląstelès gamina histaminą, serotoniną ir kininus, kurie didina kapiliarų ir ląstelių membranų pralaidumą. Iš dirbančių raumenų ir kitų organų atkeliavę įvairūs metabolitai, elektrolitai ir fermentai patenka ị kraują, pakeičia kraujo sudètị bei ypatybes, sutrikdo jo homeostazę (Hubble, 2004; Smith, Taylor, 2005; 2008).

Medžiagų apykaitos pasikeitimai per ištvermès rungtis siejasi su organizmo dehidratacija, elektrolitų ir kraujo dujų parametrų pasikeitimu, stipriu prakaitavimu (Foreman et al., 1996; Hess et al., 2008; Fieldieng, 2009; Trigo, 2010; Lawrie, 2012). Vieni iš startavusių žirgų baigia distanciją, kiti yra 
diskvalifikuojami dèl medžiagų apykaitos sutrikimų, miopatijų, širdies ir kraujagyslių sistemos miopatijos arba sutrikimų, atsiradusio šlubavimo, pasireiškusių dieglių (Fielding, Dechant, 2012) ar kitų priežasčių (Schott et al., 2006; Hess et al., 2008; Fielding et al., 2009; Alexander, Haines, 2012). Todèl labai svarbu kontroliuoti visus fiziologinius organizmo procesus, vystyti geras organizmo adaptacines funkcijas ir tinkamai paruošti žirgą fiziniam krūviui (Whiting, 2009). Išmanant organizmo parametrų pokyčius, galima reguliuoti organizmo atsistatymo procesus paspartinant raumenų aktyvumą, prisitaikymą (Nagy et al., 2010; Trigo, 2010).

Šio darbo tikslas - ištirti kraujo biocheminių ir morfologinių rodiklių kitimą po fizinio krūvio ir nustatyti diagnostines bei prognozès kraujo rodiklių reikšmes kaip vertinimo kriterijus.

\section{TYRIMŲ METODAI IR SĄLYGOS}

2011 m. gegužès ir rugpjūčio mèn. per ištvermès sporto varžybas Lietuvoje ištirti ir įvertinti 40-ties kliniškai sveikų senojo tipo žemaitukų veislès žirgu kraujo méginiai. Žirgai su raiteliais dalyvavo ištvermès sporto varžybose (Kurtuvenuose ir Tytuvenuose), bėgo $32 \mathrm{~km}$ ištvermès trasą. Iprasta, kad varžybų pradžioje žirgai pristatomi i veterinarinio patikrinimo punktą (vet. vartai). Žirgo sveikatos būklę tikrina veterinarijos gydytojas, vadovaudamasis FEI (Federation Equestre Internationale) nustatytu reglamentu. Varžybų trasa padalinta $\mathfrak{i}$ dvi dalis (pagal FEI nustatytus reglamentus). Žirgai tiriami trijuose skirtinguose veterinarijos patikrinimo punktuose: prieš lenktynes, po 16 ir $32 \mathrm{~km}$. Startuoti leidžiama po pradinio veterinarinio patikrinimo tik kliniškai sveikiems, paskiepytiems žirgams, turintiems tvarkingus registracijos pasus.

Veterinarinio patikrinimo punkte FEI patvirtintame protokole pažymimas atvykimo laikas ir atliekamas veterinarinis patikrinimas pagal FEI protokolą. Po veterinarinio patikrinimo, jeigu žirgas pripažistamas kliniškai sveiku, duetui (raitelis ir žirgas) leidžiama rungtyniauti toliau, $\mathfrak{i}$ kitą etapą išjoja po $30 \mathrm{~min}$. (jei nuostatuose nenumatyta kitaip) nuo žirgo veterinarinio patikrinimo pradžios. Kirtus finišo liniją, žirgas veterinarinei komisijai gali būti pristatomas tik vieną kartą per $30 \mathrm{~min}$. Po veterinarinio patikrinimo varžybas gali tęsti tik sveiki žirgai: kurie nešlubuoja, negirdimi širdies, kvėpavimo, virškinimo sistemu sutrikimai, nepastebima raumenų tonuso pakitimų, matomų sužeidimų. Jei atliekant veterinarini patikrinimą pastebètas žirgo sveikatos būklès pasikeitimas, pagal FEI protokolą jis yra diskvalifikuojamas.

Kraujo mėginiai morfologiniams ir biocheminiams kraujo tyrimams $(\mathrm{n}=40)$ imti iš kliniškai sveikų žemaitukų veislès žirgų, sukeliant jiems minimalų stresą: prieš varžybas ir po varžybų, praejus veterinarini patikrinimą (po varžybų).

Kraujo meginiai ( $5 \mathrm{ml}$ kraujo) buvo imti iš vena jugularis i du vakuuminius mègintuvèlius naudojant $21 \mathrm{G}$ dydžio adatą: su etilendiaminotetraacto rūgštimi (EDTA) ir mègintuvèlis su krešejjimo aktyvatoriumi (BD Vacutainer, Jungtinè Karalystè). Mègintuvèliai su EDTA buvo naudojami kraujo morfologiniams tyrimams, o mégintuvèliai su krešejimo aktyvatoriumi - kraujo biocheminiams tyrimams. Mègintuvèliai su kraujo krešejjimą stabdančiais priedais paèmus kraują lengvai vartomi rankoje, kad kraujas susimaišytų, tačiau nekratomi, kad neįvyktų hemolizès. Kraujas, skirtas biocheminiams tyrimams, nedelsiant įstatomas ị laikikli, nevartomas.

Kraujo méginiai sunumeruojami, sudedami i transportavimui skirtą šaldytuvą $\left(0-4{ }^{\circ} \mathrm{C}\right)$, gabenami į LSMU VA tyrimų bazes.

Kraujo morfologiniai parametrai vertinti automatiniu morfologiniu analizatoriumi „Abacus Junior Vet“ (Diatron Messtechnik GmbH, Austrija, 2006) LSMU VA Stambiujų gyvulių klinikos Klinikinejje laboratorijoje. Nustatyti bendri eritrocitu (RBC) ir leukocitu (WBC), limfocitu (LYM) bei trombocitu (PLT) kiekiai, hemoglobino (Hb) koncentracija, hematokritas (HCT) bei apskaičiuoti vidutinis eritrocito tūris $(\mathrm{MCV})$, vidutinis hemoglobino tūris $(\mathrm{MCH})$ ir vidutinè hemoglobino koncentracija eritrocite ( $\mathrm{MCHC})$.

Biocheminiai kraujo tyrimai atlikti LSMU VA Neužkrečiamųjų ligų katedros Gyvulių reprodukcijos laboratorijoje automatizuotu kompiuteriniu biocheminiu analizatoriumi SELECTRA Junior (Nyderlandai, 2006). Tyrimams buvo naudojami Spinreact firmos reagentai (Ispanija). Nustatytos bendrų baltymų (TP), albumino (Alb), kalcio $(\mathrm{Ca})$, fosforo $(\mathrm{P})$, magnio $(\mathrm{Mg})$, kalio $(\mathrm{K})$, natrio $(\mathrm{Na})$, šlapalo (Urea), gliukozès (Glu), kreatinino (Crea) koncentracijos, širdies (CK-MB) bei bendros (CK-NAC) kreatininkinazès koncentracijos, 
alaninaminotransferazès (ALT), aspartataminotransferazès (AST), šarminès fosfatazès (ALP) ir gamaglutamiltransferazès (GGT) aktyvumai.

Tyrimų duomenys apdoroti SPSS statistiniu paketu (SPSS for Windows 15.0, SPSS Inc., Chicago, IL, USA, 2006) ir Microsoft Office Excel (2007) programa. Kraujo morfologiniai ir serumo biocheminiai parametrai palyginti naudojant ANOVA modeli, nustatyti veiksniai prieš ir po rungtynių. Skirtumas tarp tiriamųjų grupių ivertintas dispersinès analizès metodu (F kriterijus ir p reikšmè). Parametrų analizès duomenys yra statistiškai patikimi, kai $\mathrm{p}<0,05, \mathrm{p}<0,01$ ir $\mathrm{p}<0,001$. Kraujo parametrų vidutinès normos pateiktos su standartiniu nuokrypiu.

\section{TYRIMŲ REZULTATAI IR JŲ APTARIMAS}

Ankstesniajame darbe (Miknienė ir kt., 2014) žemaitukų veislès žirgams buvo nustatytos kraujo rodiklių fiziologinès ribos ir pagal jas žirgai buvo priskirti „šiltakraujų“ žirgų kraujo tipui. Šiame tyrime vertinant žemaitukų veislès žirgų kraujo morfologinių ir biocheminių rodiklių kitimus varžybų metu buvo vadovaujamasi atlikto tyrimo kraujo fiziologinių rodiklių nustatytomis kraujo ribomis. Visi morfologiniai kraujo rodiklių kiekiai per varžybas svyravo nustatytose žemaitukų veislès žirgų fiziologinèse ribose (Miknienè ir kt., 2014).

Žemaitukų veislès žirgų kraujo morfologiniu ir biocheminių rodiklių kitimai ištvermès sporto varžybų metu pateikti 1 ir 2 lentelèse.

Atlikus kliniškai sveikų senojo tipo žemaitukų veislès žirgų morfologini kraujo tyrimą ištvermès sporto varžybu metu, nustatyta, kad WBC $(\mathrm{p}<0,05)$ ir RBC $(\mathrm{p}<0,001)$ kiekiai, $\mathrm{Hb}(\mathrm{p}<0,001)$ koncentracija ir HCT $(\mathrm{p}<0,001)$ koncentracijos bei MCHC $(\mathrm{p}<0,05)$ kiekiai statistiškai patikimai didesni nei prieš varžybas (žr. 1 lentelę).

Iš karto po finišo pastebimas fiziologinis statistiškai patikimas $(\mathrm{p}<0,001)$ bendras eritrocitų kiekio (RBC), hemoglobino koncentracijos ( $\mathrm{Hb}$ ) ir hematokrito (HCT) padidejimas. Tai rodo padidèjęs kraujo klampumas, kuri stipriai prakaituojant per varžybas sukelia organizmo dehidratacija (Aguilera-Tejero et al., 2000; Schott et al., 2006; Borodkina, 2008; Sergienko, 2008; Barnes et al., 2010).

Po varžybų dèl blužnies susitraukimų ir suaktyvejusios hemokoncentracijos padideja $\mathrm{HCT}$ ir $\mathrm{Hb}$ koncentracijos (Baloch et al., 2001; Taylor, Hillyer,

1 lentelè. Žemaitukų veislès žirgų kraujo morfologinių rodiklių vidutinės normos su standartiniu nuokrypiu ištvermès sporto varžybose $(32 \mathrm{~km})$

Table 1. Mean value with standard deviation (SD) of blood hematological parameters in Žemaitukai horses during a $32 \mathrm{~km}$ endurance race

\begin{tabular}{|c|c|c|c|c|c|c|}
\hline \multirow{2}{*}{$\begin{array}{l}\text { Parametrai } \\
\text { Parameters }\end{array}$} & \multicolumn{2}{|c|}{$\begin{array}{c}\text { Prieš varžybas } \\
\text { Pre race }\end{array}$} & \multicolumn{2}{|c|}{$\begin{array}{l}\text { Po varžybų } \\
\text { Post race }\end{array}$} & \multirow[t]{2}{*}{ F } & \multirow[t]{2}{*}{ Sig. } \\
\hline & & SD & & SD & & \\
\hline WBC, $\times 10^{9} / 1$ & 10,12 & 2,17 & 11,15 & $2,29^{*}$ & 4,016 & 0,0490 \\
\hline LYM, $\times 10^{9} / 1$ & 1,51 & 0,61 & 1,22 & $0,54^{*}$ & 4,700 & 0,0330 \\
\hline GRA, $\times 10^{9} / 1$ & 8,16 & 2,18 & 9,34 & $2,31^{*}$ & 5,220 & 0,0250 \\
\hline $\mathrm{RBC}, \times 10^{12} / \mathrm{l}$ & 8,31 & 1,02 & 9,34 & $0,97^{\star \star *}$ & 20,154 & 0,0000 \\
\hline $\mathrm{Hb}, \mathrm{g} / \mathrm{l}$ & 127,90 & 16,48 & 143,97 & $15,29^{* * *}$ & 19,293 & 0,0000 \\
\hline HCT, \% / PCV, \% & 36,22 & 4,28 & 40,16 & $3,90^{* * *}$ & 17,476 & 0,0000 \\
\hline $\mathrm{MCV}, \mathrm{fl}$ & 43,93 & 2,99 & 43,11 & 2,91 & 1,441 & 0,2340 \\
\hline $\mathrm{MCH}, \mathrm{pg}$ & 15,34 & 1,22 & 15,45 & 1,07 & 0,180 & 0,6730 \\
\hline $\mathrm{MCHC}, \mathrm{g} / \mathrm{l}$ & 348,38 & 25,47 & 358,67 & $10,30^{*}$ & 5,121 & 0,0270 \\
\hline PLT, $\times 10^{9} / 1$ & 166,08 & 62,44 & 193,50 & 2,12 & 0,373 & 0,5470 \\
\hline
\end{tabular}

${ }^{*}-\mathrm{p}<0,05 ;{ }^{* *}-\mathrm{p}<0,01 ;{ }^{* * *}-\mathrm{p}<0,001$.

Pastaba: WBC - bendrųjų leukocitų kiekis, LYM - limfocitų kiekis, GRA - granuliocitų kiekis, RBC - bendrųjų eritrocitų kiekis, $\mathrm{Hb}$ - hemoglobino koncentracija, $\mathrm{HCT}$ - hematokritas, MCV - vidutinis eritrocito tūris, $\mathrm{MCH}$ - vidutinis hemoglobino tūris, MCHC - vidutinè hemoglobino koncentracija eritrocite, PLT - trombocitų kiekis.

Note: RBC - red blood cell, WBC - white blood cell, Hb - hemoglobin concentration, PCV - hematocrit, LYM - lymphocytes, GRA - granulocytes, PLT - platelet, MCV - mean cell volume, $M C H$ - mean cell hemoglobin, $M C H C$ - mean cell hemoglobin concentration. 
2001). Panašius svyravimus po fizinio krūvio pastebejo ir H. Schott (2006), A. Munoz (1998) bei kiti mokslininkai (Borodkina, 2008; Sergienko, 2008; Larson et al., 2013), taip pat nurodè svorio mažejimą bei dehidrataciją dèl gausaus prakaitavimo (Aguilera-Tejero et al., 2000; Schott et al., 2006; Borodkina, 2008; Sergienko, 2008; Larson et al., 2013). RBC, Hb ir HCT kiekiu padidejimus po varžybų dar galima paaiškinti suintensyvejusia plaučių ventiliacija ir širdies bei kraujagyslių sistemos darbu krūvio metu.

Limfocitu kiekis leukogramoje atspindi imuninę sistemą, funkcinę žirgo būklę ir nespecifinès adaptacijos tipą (Hinchliff et al., 2008). Varžybų metu suaktyvèja adaptacinès sistemos procesai (1 lentelè), dèl to WBC kiekio verte $10,18 \%$ statistiškai patikimai padideja, pasikeičia granuliocitų-limfocitų santykis, o limfocitų procentinè išraiška (LY \%) tampa 23,77 \% statistiškai patikimai mažesnè, palyginti su rezultatu prieš varžybas.
Nustatyta, kad po varžybų bendras trombocitų (PLT) kiekis statistiškai nepatikimai padidejo $16,51 \%$. Kai kurie autoriai pastebejo padidejusi varžybose dalyvaujančių žirgų kraujo klampumą, sumažejusị krešèjimo laiką (Munoz et al., 1998; Piccione et al., 2008; Barnes, 2010).

Biocheminiais kraujo tyrimais nustatyta, kad po varžybų žemaitukų veislès žirgų kraujo serume vidutiniai bendrujų baltymų (TP) kiekiai statistiškai patikimai $(\mathrm{p}<0,01)$ mažesni nei prieš varžybas, atitinkamai mažesnis ir albumino (Alb) kiekis $(\mathrm{p}<0,05)$. Gliukozès (Glu) $(\mathrm{p}<0,01)$, kreatinino (Crea), natrio $(\mathrm{Na})$ kiekiai statistiškai patikimai didesni $(\mathrm{p}<0,001)$, kaip ir fermento CK-NAC $(\mathrm{p}<0,05)$, nei prieš varžybas.

Nustatyta, kad AST, ALT, CK-MB aktyvumas, kalio $(\mathrm{K})$, kalcio $(\mathrm{Ca})$ ir fosforo $(\mathrm{P})$ kiekiai statistiškai nepatikimai didesni nei prieš varžybas, o šlapalo (Urea) ir šarminès fosfatazès (ALP) - mažesni (žr. 2 lentelę).

2 lentelè. Žemaitukų veislès žirgų kraujo biocheminių rodiklių vidutinės normos su standartiniu nuokrypiu ištvermès sporto varžybose $(32 \mathrm{~km})$

Table 2. Mean value with standard deviation (SD) of serum biochemical parameters in Žemaitukai horses during a $32 \mathrm{~km}$ endurance race

\begin{tabular}{|c|c|c|c|c|c|c|}
\hline \multirow{2}{*}{$\begin{array}{l}\text { Parametrai } \\
\text { Parameters }\end{array}$} & \multicolumn{2}{|c|}{$\begin{array}{c}\text { Prieš varžybas } \\
\text { Pre race }\end{array}$} & \multicolumn{2}{|c|}{$\begin{array}{l}\text { Po varžybų } \\
\text { Post race }\end{array}$} & \multirow[t]{2}{*}{$\mathbf{F}$} & \multirow[t]{2}{*}{ Sig. } \\
\hline & & SD & & SD & & \\
\hline $\mathrm{TP}, \mathrm{g} / \mathrm{l}$ & 71,29 & 7,13 & 66,33 & $7,54^{\star *}$ & 8,372 & 0,0050 \\
\hline Alb, g/l & 32,08 & 3,88 & 29,07 & $6,60^{*}$ & 5,719 & 0,0190 \\
\hline Glu, mmol/l & 3,27 & 1,10 & 4,39 & $1,94^{* *}$ & 9,533 & 0,0030 \\
\hline Urea, mmol/l & 5,84 & 1,79 & 5,77 & 1,58 & 0,029 & 0,8640 \\
\hline Crea, mg/l & 0,85 & 0,13 & 1,00 & $0,22^{* * *}$ & 11,699 & 0,0010 \\
\hline AST, TV/l & 355,64 & 97,50 & 374,19 & 115,32 & 0,547 & 0,4620 \\
\hline ALT, TV/1 & 14,44 & 6,35 & 22,15 & 32,71 & 2,032 & 0,1580 \\
\hline ALP, TV/l & 391,32 & 126,49 & 373,63 & 152,12 & 0,294 & 0,5900 \\
\hline GGT, TV/1 & 25,71 & 11,32 & 27,24 & 13,29 & 0,281 & 0,598 \\
\hline CK-MB U/1 & 603,45 & 232,05 & 673,79 & 298,81 & 1,149 & 0,2880 \\
\hline CK-NAC U/l & 376,29 & 149,48 & 476,06 & $238,61^{*}$ & 4,197 & 0,0450 \\
\hline $\mathrm{Mg}, \mathrm{mmol} / \mathrm{l}$ & 0,63 & 0,08 & 0,60 & 0,79 & 2,453 & 0,122 \\
\hline $\mathrm{K}, \mathrm{mmol} / \mathrm{l}$ & 5,29 & 0,69 & 5,34 & 1,24 & 0,047 & 0,8290 \\
\hline $\mathrm{Na}, \mathrm{mmol} / \mathrm{l}$ & 154,23 & 2,54 & 157,36 & $3,69^{* * *}$ & 16,373 & 0,0000 \\
\hline $\mathrm{Ca}, \mathrm{mmol} / \mathrm{l}$ & 2,59 & 0,27 & 2,65 & 0,48 & 0,511 & 0,4770 \\
\hline $\mathrm{P}, \mathrm{mmol} / \mathrm{l}$ & 0,96 & 0,24 & 1,00 & 0,33 & 0,306 & 0,5820 \\
\hline
\end{tabular}

${ }^{*}-\mathrm{p}<0,05 ;{ }^{* *}-\mathrm{p}<0,01 ;{ }^{* * *}-\mathrm{p}<0,001$.

Pastaba: TP - bendrųjų baltymų kiekis, Alb - albuminų kiekis, Glu - gliukozė, Urea - šlapalas, Crea - kreatininas, AST - aspartataminotransferazė, ALT - alaninaminotransferazės, GGT - gamaglutamiltransferazè, CK-MB - kreatinkinazè, širdies izomeras, CK-NAC - kreatinkinazės bendras kiekis, $\mathrm{Mg}$ - magnis, $\mathrm{K}$ - kalis, $\mathrm{Na}$ - natris, $\mathrm{Ca}$ - kalcis, $\mathrm{P}$ - fosforas.

Note: TP - total protein, Alb - albumin, Glu - glucose, Urea - urea, Crea - creatinine, AST - aspartate aminotransferase, $A L T$ - alanine aminotransferase, GGT - gamaglutamiltransferase, CK-MB - heart creatinekinase, CK-NAC - total creatinekinase, $\mathrm{Mg}$ - magnesium, $\mathrm{K}$ - potassium, $\mathrm{Na}$ - sodium, $\mathrm{Ca}$ - calcium, $\mathrm{P}$ - phosphorum. 
Padidejję fermentų AST, CK-MB, CK-NAC, GGT ir ALT kiekiai signalizuoja apie dideli fizinị krūvị, tenkantị rungtyniaujančiam žirgui. Visi penki fermentai dalyvauja baltymu apykaitoje ir prisideda prie energijos kaupimo substrato formavimo (Marlin et al., 2002; Hinchliff et al., 2008).

Nustatyta, kad AST ir ALT aktyvumo kiekiai atitinkamai 5,22 ir 53,40 \% didesni po varžybų, panašius pokyčius pastebejo ir kiti mokslininkai (Larson et al., 2013). Reikia pažymèti, kad AST aktyvumo kiekis po varžybų svyruoja, bet atitinka žemaitukų veislès žirgų fiziologines normas (Mikniené ir kt., 2014). Taigi raumenų darbas neturi jokio patologinio poveikio fiziologinèms žirgo organizmo sistemoms.

Po varžybų šarminès fosfatazès (ALP) aktyvumas 4,52 \% statistiškai nepatikimai sumažeja, palyginti su rezultatu prieš varžybas. Šarminès fosfatazès kiekis yra ištvermès sporto varžybose dalyvaujančių žirgų fizinio streso indikatorius (Hinchliff et al., 2008). Padideję̧s ALP žirgų kraujo serume atsistatymo periodu po varžybu nurodo fiziologinių organizmo sistemų, taip pat ir skeleto raumenų sistemos, ittempimą. ALP organizmo adaptacijos procese atlieka raumenu veiklos apsauginę funkciją. Todèl mūsų tyrimo metu nežymus šio fermento kiekio sumažèjimas liudija apie tinkamą raumenų pasiruošimą fiziniam krūviui.

Nustatyta, kad po varžybų šlapalo (Urea) vertė $1,20 \%$ statistiškai nepatikimai mažesnè nei prieš varžybas. Šlapalas yra galutinis baltymų skilimo produktas. Didelis ištvermès sporto varžybose dalyvavusių žirgų šlapalo sumažèjimas liudija apie baltymų irimo aktyvumo sumažèjimą, tai nutinka žirgams prarandant sportinę formą (Hinchliff et al., 2008).

Fermento CK-NAC aktyvumas $26,52 \%$ statistiškai patikimai $(\mathrm{p}<0,05)$ didesnis po varžybų, palyginti su rezultatu prieš varžybas. Fermento CK-NAC aktyvumo padidejimas siejamas su intensyviu raumenų darbu, išaugusiu raumeninių skaidulu membranos pralaidumu (Balogch et al., 2001; Valberg, 2009; Cywinska et al., 2012).

Ištvermès sporto varžybose žemaitukų veislès žirgai jaučia stresą bei nuovargi, tai aiškiai atskleidžia cirkuliuojančių eritrocitų ir leukocitų skaičiaus svyravimai ir kintanti kreatinino koncentracija. Ištvermés sporto varžybose taip pat vyksta audinių rekonstrukcija, tai įrodo plazmos fibrinogeno, šlapalo, baltymų ir kreatinkinazès (CK) pokyčiai kraujo serume (Larson et al., 2013).

Kreatininas (Crea) yra galutinis kreatinfosfato skilimo produktas (Piccione et al., 2008). Nustatyta, kad po varžybų senojo tipo žemaitukų veislès žirgų kraujyje Crea verte 17,64 \% statistiškai patikimai $(\mathrm{p}<0,001)$ padidejo, palyginti su rezultatu, gautu prieš varžybas.

Gliukozè yra pagrindinè angliavandenių apykaitos medžiaga (Kerr, 2002). Gliukozès koncentraciją kraujyje reguliuoja insulinas ir glikogenas, tačiau yra kitų veiksnių, turinčių ịtakos gliukozès kiekiui serume (Kaneko et al., 2008). Tyrimo metu nustatyta, kad po varžybų senojo tipo žemaitukų veislès žirgų kraujyje Glu koncentracijos kiekis 34,25 \% statistiškai patikimai $(\mathrm{p}<0,01)$ padidejo, palyginti su kiekiu prieš varžybas. M. G. Kerr (2002) duomenimis, padidejus raumenų darbo intensyvumui, organizme padideja gliukozès poreikis (energijos gamybai) (Kerr, 2002).

Po varžybų senojo tipo žemaitukų veislès žirgų kraujyje bendrųjų baltymų kiekis (TP) 6,96 \% (žr. 2 lentelę) statistiškai patikimai $(\mathrm{p}<0,01)$ mažesnis, o albumino kiekis - (Alb) 9,38 \% statistiškai patikimai $(\mathrm{p}<0,05)$ mažesnis nei prieš varžybas. Manoma, kad priežastis - suaktyvejusi baltymų apykaita intensyviai dirbant raumenims. C. Robert ir kt. (2010) duomenimis, kuo mažesnis albumino frakcijos kiekis kraujyje, tuo mažesnis organizmo atsparumas kintančioms sąlygoms, gebejjimas prisitaikyti ir atstatyti homeostazę (Robert et al., 2010).

Po varžybų kalcio $(\mathrm{Ca})$ kiekis žemaitukų veislès žirgų kraujyje $81,46 \%$ padidejjo. Kalcio jonai svarbūs nervinio impulso plitimui ị raumenų ląsteles, širdies veiklai, kraujo krešejimui, kaulinio audinio formavimuisi, raumenų susitraukimui, medžiagų apykaitos procesams, ląstelių pralaidumui, rūgščių ir šarmų pusiausvyrai (Taylor, Hillyer, 2001; Diakakis, 2002; Hess, 2005; Feldman et al., 2006; Kaneko et al., 2008). Kalcis perduoda nervinius impulsus širdžiai, ypač prieširdžių ir skilvelių mazge, todèl žirgams gali sukelti širdies ritmo sutrikimus. Ištvermès sporto varžybose dalyvaujančių žirgų organizmui reikia kalcio (raumenų susitraukimams), o mažas jo kiekis kraujo plazmoje per sunkias ištvermès varžybas gali sukelti medžiagu apykaitos sistemos sutrikimus, net ir sinchroninị diafragmos plazdejimą (Bergero et al., 2005). 
Hiperkalcemija per ištvermès rungtynes gali padidinti širdies susitraukimu dažni (Adamu et al., 2012). Pažymètina, kad Ca kiekis žemaitukų žirgu kraujyje per varžybas atitiko nustatytas ribas, nors ir svyravo (Miknienè ir kt., 2014).

Po varžybų sumažèja žemaitukų veislès žirgų magnio (Mg) kiekis. Efektyviam fermentų funkcionavimui dažnai reikia specialių medžiagų - aktyvatorių, tai paprastai yra metalo jonai (dažniausiai dvivalenčiai $\mathrm{Mg}, \mathrm{Ca}$ jonai) (Praškevičius ir kt., 2003). Serume nustatomo magnio kiekis sudaro apytikriai vieną procentą viso organizmo magnio (Fielding, 2009). Magnio kiekis dešimt kartų didesnis raumenyse nei kraujo plazmoje, todèl jis gali išlikti stabilus net esant ilgalaikiam jo netekimui (pasipildant iš raumenų) (Johnson et al., 1999; Hinchliff et al., 2008).

Kalis (K) yra svarbiausias ląstelių katijonas, daug jo yra raumenyse. Tarpląstelinëje terpèje yra maždaug $2 \%$ kalio, kuris tolygiai pasiskirsto kraujo plazmoje ir tarpląsteliniame skystyje. Kalio jonu kiekis palaikomas dèl jo nuolatinių kaupimosi savybiu (Kerr, 2002; Bergero et al., 2005; Hinchcliff, 2008; Munoz et al., 2008; Fielding, 2009). Po varžybų žemaitukų veislès žirgų kraujyje K kiekis 0,94 \% padidejo, palyginti su kiekiu prieš varžybas.

Natris (Na) yra svarbiausias neląstelinis elektrolitas (katijonas), reguliuojantis vandens apykaitą. Ketvirtadalis organizme esančio natrio įeina $\mathfrak{i}$ audinių sudètị, kita dalis yra neląsteliniame skystyje ir nuolat keičiasi. Nustatyta, kad po varžybų žemaitukų veislès žirgų kraujyje Na kiekis 2,03 \% statistiškai patikimai $(\mathrm{p}<0,001)$ didesnis nei prieš varžybas.

$\mathrm{Na}$ ir K padidejjimas siejamas su dideliu prakaitavimu (dirbant raumenims) (Bergero et al., 2005; Munoz et al., 2008). C. Fielding ir kt. (2009) pastebejo panašius (kaip ir mūsų tiriamajame darbe) kraujo parametru $(\mathrm{Na}+, \mathrm{K}+, \mathrm{HCT}, \mathrm{TP})$ pakitimus kraujyje. Nustatyta, kad per varžybas žirgų organizme vyksta reikšmingi morfologiniai ir biocheminiai kraujo rodiklių pokyčiai.

\section{IŠVADOS}

1. Atlikus kliniškai sveikų senojo tipo žemaitukų veislès žirgų morfologinị kraujo tyrimą ištvermès sporto varžybu metu, nustatyta, kad bendras leukocitu (WBC) 10,18 \% ( $<0,05)$ ir bendras eritrocitu $(\mathrm{RBC}) 12,39 \%(\mathrm{p}<0,05)$ kiekiai, Hb 12,56 \% $(\mathrm{p}<0,001)$ ir HCT $10,88 \%(\mathrm{p}<0,001)$ koncentra- cijos bei MCHC 2,95 \% ( p < 0,05) kiekiai statistiškai patikimai didesni nei prieš varžybas.

2. Biocheminiais kraujo tyrimais nustatyta, kad žemaitukų veislès žirgu po varžybų kraujo serume vidutiniai bendrųjų baltymų (TP) kiekiai 8,88\% statistiškai patikimai $(\mathrm{p}<0,01)$ mažesni nei prieš varžybas, mažesnis ir albumino (Alb) kiekis 9,38 \% ( $\mathrm{p}<0,05)$. Gliukozės (Glu) 34,25\% ( $<<0,01)$, kreatinino (Crea) 17,65 \%, natrio (Na) 2,03 \% kiekiai statistiškai patikimai didesni $(\mathrm{p}<0,001)$, bendro kreatinkinazès fermento (CK-NAC) 25,51\% $(\mathrm{p}<0,05)$ aktyvumas didesnis nei prieš varžybas.

3. Varžybų metu žirgų fizinis pasirengimas, patvirtintas kraujo morfologinių ir biocheminių parametrų kitimų, yra pakankamai aukštas ir atitinka ištvermès sporto varžybose dalyvaujančių žirgu kraujo morfologinių ir biocheminių parametru pokyčius.

Gauta 20140714

Priimta 20141210

\section{LITERATŪRA}

1. Adamu L., Noraniza M. A., Rasedee A., Bashir A. 2012. Prevalence of lameness and metabolic disorders in endurance horses. Malaysian Journal of Veterinary Research. P. 33-37.

2 Aguilera-Tejero E., Estepa J. C., Lopez I., Bas S., Mayer-Valor R., Rodriguez M. 2000. Quantitative analysis of acidbase balance in show jumpers before and after exercise. Research in Veterinary Science. Vol. 68. P. 103-108.

3. Alexander G. R., Haines G. R. 2012. Surgical colic in racing endurance horses. Equine Veterinary Education. Vol. 24. P. 193-199.

4. Balogh N., Gaal T., Ribiczeyné P. S. 2001. Biochemical and antioxidant changes in plasma and erythrocytes of pentathlon horses before and after exercise. Veterinary Clinical Pathology. Vol. 30. P. 214-218.

5. Barnes A., Kingston J., Beetson S., Kuiper C. 2010. Endurance veterinarians detect physiologically compromised horses in a $160 \mathrm{~km}$ ride. Equine Veterinary Journal. Vol. 42. P. 6-11.

6. Bergero D., Assenza A., Caola G. 2005. Contribution to our knowledge of the physiology and metabolism of endurance horses. Journal of Livestock Pro Science. Vol. 92. P. 167-176.

7. Borodkina E. J. 2008. Pokazateli krovi plemennyh i sportivnyh loshadej $v$ svjazi s funkcionalnym sostojaniem. Dissertacija na soiskanie uchionoj stepeni kandidata biologicheskih nauk. 167 p.

8. Cywinska A., Szarska E., Gorecka R., Witkowski L., Hecold M., Bereznowski A., Schollenberg A., 
Winnicka A. 2012. Acute phase protein concentrations after limited distance and long distance endurance rides in horses. Research in Veterinary Science. Vol. 93. Nr. 3. P. 1402-1406.

9. Diakakis N., Mylonakis M. E., Roubies N., Koutinas C., Fytianou A., Koutinas A. F. 2002. Reference values of 23 clinically important biochemical parameters in 107 normal pleasure horses residing in northern Greece. Journal of the Hellenic Veterinary Medical Society. Vol. 53. Nr. 2. P. 138146.

10. Feldman F. B., Zinkl G. J., Jain N. C. 2006. Schalm's Veterinary Hematology. 5th ed. Blackwell Publishing, Ltd. 1232 p.

11. Fielding C. L. 2009. Clinical and biochemical abnormalities in endurance horses eliminated from competition for medical complications and requiring emergency medical treatment: 30 cases (2005-2006). Journal of Veterinary Emergency and Clinical Care. Vol. 19. No. 5. P. 473-478.

12. Fielding C. L., Meier C. A., Balch O. K., Kass P. H. 2011. Risk factors for the elimination of endurance horses from competition. Journal of American Veterinary Medicine Association. Vol. 239. P. 493498.

13. Fielding C. L., Dechant J. E. 2012. Colic in competing endurance horses presenting to referral centres: 36 cases. Equine Veterinary Journal. Vol. 44. P. 472-475.

14. Hess M. T., Greiwe-Crandell K. M., Waldron J. E., Williams C. A., Lopes M. A., Gay L. S., Harris P. A., Kronfeld D. S. 2008. Potassium-free electrolytes and calcium supplementation in an endurance race. Comparative Exercise Physiology. Vol. 5(1). P. 33-41.

15. Hess M. T. 2005. Potassium-free and potassiumcontaining electrolytes affect plasma ions and acidbase status of endurance horses: Dissertation of DPh. 252 p.

16. Hinchcliff K. W., Kaneps A. J., Geor R. J. 2008. Equine Exercise Physiology: The Science of Exercise in the Athletic Horse. Elsevier Health Sciences. $466 \mathrm{p}$.

17. Hubble S. M. 2004. Acid-base and blood gas analysis. Original Research Article. Anaesthesia and Intensive Care Medicine. Vol. 5. P. 380-383.

18. Johnson A., Rohlfs E., Silverman L. 1999. Proteins. In: C. A. Burtis, E. R. Ashwood, editors. Tietz Textbook of Clinical Chemistry. 3rd edn. Philadelphia: W. B. Saunders Company. P. 477-540.

19. Kaneko J. J., Harvey J. W., Bruss M. 2008. Clinical Biochemistry of Domestic Animals. 6th edn. Singapore: Harcourt Bruce and Co. Asia PTE Ltd. P. 619-680.

20. Kerr M. G. 2002. Veterinary Laboratory Medicine. Clinical Biochemistry and Haematology. Second edition. Oxford, London, Edinburgh, Boston, Melbourne: Blackwell Scientific Publications. 369 p.
21. Larson J., Pilborg P. H., Jahansen M., Christophersen M. T., Holte A., Roepstorff L., Olsen L. H., Harrison A. P. 2013. Physiological Parameters of Endurance Horses Pre-compared to Post-race, Correlated with Performance: A Two Race Study from Scandinavia. ISRN Veterinary Science. Article ID 684353. P. 1-12.

22. Lawrie C. H. 2012. Hematology - Science and Practice. Croatia. 596 p.

23. Marlin D. J., Fenn K., Smith N., Deaton C. D., Roberts C. A., Harris P. A., Dunster C., Kelly F. J. 2002. Changes in circulatory antioxidant status in horses during prolonged exercise. Journal of Nutrition. Vol. 132. P. 1622S-1627S.

24. Miknienė Z., Maslauskas K., Kerzienė S., Kučinskienè J., Kučinskas A. 2014. The effect of age and gender on blood haematological and serum biochemical parameters in Žemaitukai horses. Veterinarija ir zootechnika. Vol. 65(87). P. 37-43.

25. Munoz A., Riber C., Trigo P., Castejon F. 2008. Erythrocyte indices in relation to hydration and electrolytes in horses performing exercises of different intensity. Comparative Clinical Pathology. Vol. 17. P. 213-220.

26. Nagy A., Murray J. K., Dyson S. 2010. Elimination from elite endurance rides in nine countries: A preliminary study. Equine Veterinary Journal. Vol. 42. P. 637-643.

27. Praškevičius A., Ivanovienè L., Stasiūnienė N., Burneckienė J., Rodovičius H., Lukoševičius L., Kondratas D. 2003. Biochemija. Kaunas: KMU leidykla. P. 250-251, 370-371, 604, 612-613, 696, 699, 713, 733-735.

28. Piccione G., Vazzana I., Giannetto C., Gianesella M., Ferrantelli V. 2008. Modification of some haematological and haematochemical parameters in horse during long distance rides. Research Journal of Veterinary Sciences. Vol. 1. P. 37-43.

29. Prince A., Geor R., Harris P., Hoekstra K., Gardner S., Hudson C., Pagan J. 2002. Comparison of the metabolic responses of trained Arabians and Thoroughbreds during high- and low-intensity exercise. Equine Exercise Physiology. Vol. 34. P. 95-99.

30. Robert C., Goachet A. G., Fraipont A., Votion D. M., Erck E. 2010. Hydration and electrolyte balance in horses during an endurance season. Equine Veterinary Journal. Vol. 42. No. 38. P. 98-104.

31. Schott H. C., Marlin D. J., Georg R. J., Holbrook T. C., Deaton C. M., Vincent T., Dacre K., Schroter R. C., Jose-Cunilleras E., Cornelisse C. J. 2006. Changes in selected physiological and laboratory measurements in elite horses competing in a $160 \mathrm{~km}$ endurance ride. Equine Veterinary Journal. Vol. 36. P. 37-42.

32. Sergienko V. S. 2008. Zootehnicheskie i fiziologicheskie osobennosti sportivnykh loshadey, vystupayushchikh $v$ sorevnovaniyakh po vyezdke. 
Dissertaciya na soiskanie uchionoy stepeni kandidata selskokhoziaystvenykh nauk. $126 \mathrm{~s}$.

33. Smith A., Taylor C. 2005. Analysis of blood gases and acid-base balance. Journal of Surgeon Education (Oxford). Vol. 23. P. 194-198.

34. Smith A., Taylor C. 2008. Analysis of blood gases and acid-base balance. Journal of Surgeon Education (Oxford). Vol. 26. P. 86-90.

35. Taylor F. G. R., Hillyer M. H. 1992. The differential diagnosis of hyperglycemia in horses. Equine Veterinary Education. Vol. 4. P. 135.

36. Trigo P., Castejon F., Riber C., Munoz A. 2010. Use of biochemical parameters to predict metabolic elimination in endurance rides. Equine Veterinary Journal. Vol. 38. P. 142-146.

37. Valberg S. J. 2009. Approach the Horse with a Suspected Myopathy. Proceedings of the 11th International Congress of World Equine Veterinary Association. P. 1-15.

38. Whiting J. 2009. The exhausted horse. In: N. E. Robinson, K. A. Sprayberry, editors. Current Therapy in Equine Medicine. 6th edn. St Louis: Saunders Elsevier. P. 926-929.
Zoja Miknienè, Audrius Kučinskas

\section{EVALUATION OF BLOOD VARIABLES IN ŽEMAITUKAI HORSES DURING AN ENDURANCE RACE}

Sum mary

The aim of the present study was to investigate and evaluate changes in the biochemical and hematological parameters of Žemaitukai horse blood serum after an endurance race (32 km).

Hematological parameters (red blood cell (RBC), white blood cell (WBC), hemoglobin concentration ( $\mathrm{Hb})$, hematocrit (PCV), lymphocytes (LYM), platelet (PLT), mean cell volume $(\mathrm{MCV})$, mean cell hemoglobin $(\mathrm{MCH})$, mean cell hemoglobin concentration (MCHC)), and biochemical parameters (total protein $(\mathrm{TP})$, albumin $(\mathrm{Alb})$, calcium $(\mathrm{Ca})$, phosphorus $(\mathrm{P})$, magnesium $(\mathrm{Mg})$, potassium $(\mathrm{K})$, sodium $(\mathrm{Na})$, urea (Urea), glucose (Glu), creatinine (Crea) concentration, heart (CK-MB) and total (CK-NAC) creatinekinase, alanine aminotransferase (ALT), aspartate aminotransferase (AST), alkaline phosphatase (ALP) and gamaglutamiltransferase (GGT)) activity were determined for 40 clinically healthy Žemaitukai horses before and after the endurance race $(32 \mathrm{~km})$. It was found that the $\mathrm{WBC}(\mathrm{p}<0.05)$ and $\mathrm{RBC}$ $(\mathrm{p}<0.05)$ values, $\mathrm{Hb}(\mathrm{p}<0.001)$ values and PCV $(\mathrm{p}<0.001)$, MCH $(\mathrm{p}<0.05)$, MCHC $(\mathrm{p}<0.05)$ and PLT $(\mathrm{p}<0.05)$ were significantly higher than before the race. It was found that glucose, creatinine, sodium values $(\mathrm{p}<0.001)$, as well as the enzyme CK-NAC $(\mathrm{p}<0.01)$, were significantly higher than before the race, but serum total protein $(\mathrm{p}<0.01)$ and albumin $(\mathrm{p}<0.05)$ were statistically significantly lower than before the race. It was found that AST, ALT, CK-MB activity, potassium, calcium and phosphorus values statistically insignificantly were higher than before the race, and urea, magnesium and alkaline phosphatase values were lower. It was found that, during race, the body is experiencing significant hematological and biochemical variability.

Key words: Žemaitukai, endurance race, hematological parameters, biochemical parameters 